Article

\title{
Assessment and Management of Pressure on Water Quality Protection along the Middle Route of the South-to-North Water Diversion Project
}

\author{
Baolong Han ${ }^{1}$, Nan Meng ${ }^{1}$, Jiatian Zhang ${ }^{1,2}$, Wenbo Cai ${ }^{1}$, Tong $\mathrm{Wu}^{1}$, Lingqiao Kong ${ }^{1}$ and \\ Zhiyun Ouyang $1, *$ (1) \\ 1 State Key Laboratory of Urban and Regional Ecology, Research Center for Eco-Environmental Sciences, \\ Chinese Academy of Sciences, Beijing 100085, China; blhan@rcees.ac.cn (B.H.); \\ mnrcees@outlook.com (N.M.); Jiatian-Z@outlook.com (J.Z.); wbcai@rcees.ac.cn (W.C.); \\ tongwu15@outlook.com (T.W.); lqkong@rcees.ac.cn (L.K.) \\ 2 College of Environment and Planning, Henan University, Kaifeng 475004, China \\ * Correspondence: zyouyang@rcees.ac.cn
}

Received: 16 April 2019; Accepted: 24 May 2019; Published: 31 May 2019

\begin{abstract}
Water scarcity in densely populated areas is a global concern. In China, ensuring water supply and quality in the middle of the South-to-North Water Diversion Project has become a major challenge due to the complexity and diversity of landscape features and the trunk canal construction in the crossing area of this route. Precise assessments of the pressures on water protection along the route are urgently needed. This article provides a rigorous methodological framework to assess water quality protection, identifying the intensity of human disturbance along the route within 2-km radius buffer areas on both sides of the trunk canal, based on land-use changes from 2005 to 2015. The results show that more than 10,000 ha of pervious surfaces were transformed into impervious surfaces, leading to undesirable outcomes. The results of this study can be used for decisive support in China's environmental management, such as with main functional zoning policy and ecological red lines policy.
\end{abstract}

Keywords: human disturbance; middle route project; the South-to-North Water Diversion Project; trunk canal; water quality protection; land-use change

\section{Introduction}

Global Water Diversion Projects have been launched to alleviate severe water scarcity in densely populated areas, e.g., the West-to-North Water Transfer Project in Pakistan, the Bavaria Water Transfer Project in Germany, the National River Linking Project in India, and the South-to-North Water Diversion Project in China [1]. The middle route of the South-to-North Water Diversion Project transfers water from the first gate of the Taocha canal of the Danjiangkou reservoir in Henan Province in Central China across four administrative units proceeding north: Henan, Hebei, Beijing (China's capital), and Tianjin (Figure 1). This canal (route) runs through the Nanyang basin and the western portion of the Huang-Huai-Hai Plain. The total length of this route is about $1432 \mathrm{~km}$. The length from Henan to Beijing is $1277 \mathrm{~km}$, and the length to Tianjin is $155 \mathrm{~km}$. The aim of this project is to alleviate water scarcity in the cities along the route and to satisfy the water demand from ecosystems, manufacturing, agriculture, and residential consumption [2]. The middle route project was officially launched on 30 December 2003, and has been transferring water since 12 December 2014. Until September 2017, 9.6 billion $\mathrm{m}^{3}$ of water had been cumulatively transferred to North China, which benefited 53.1 million people. This project has great social-economic-ecological significance since it not only improves urban water quality but also reduces groundwater subsidence [3]. 


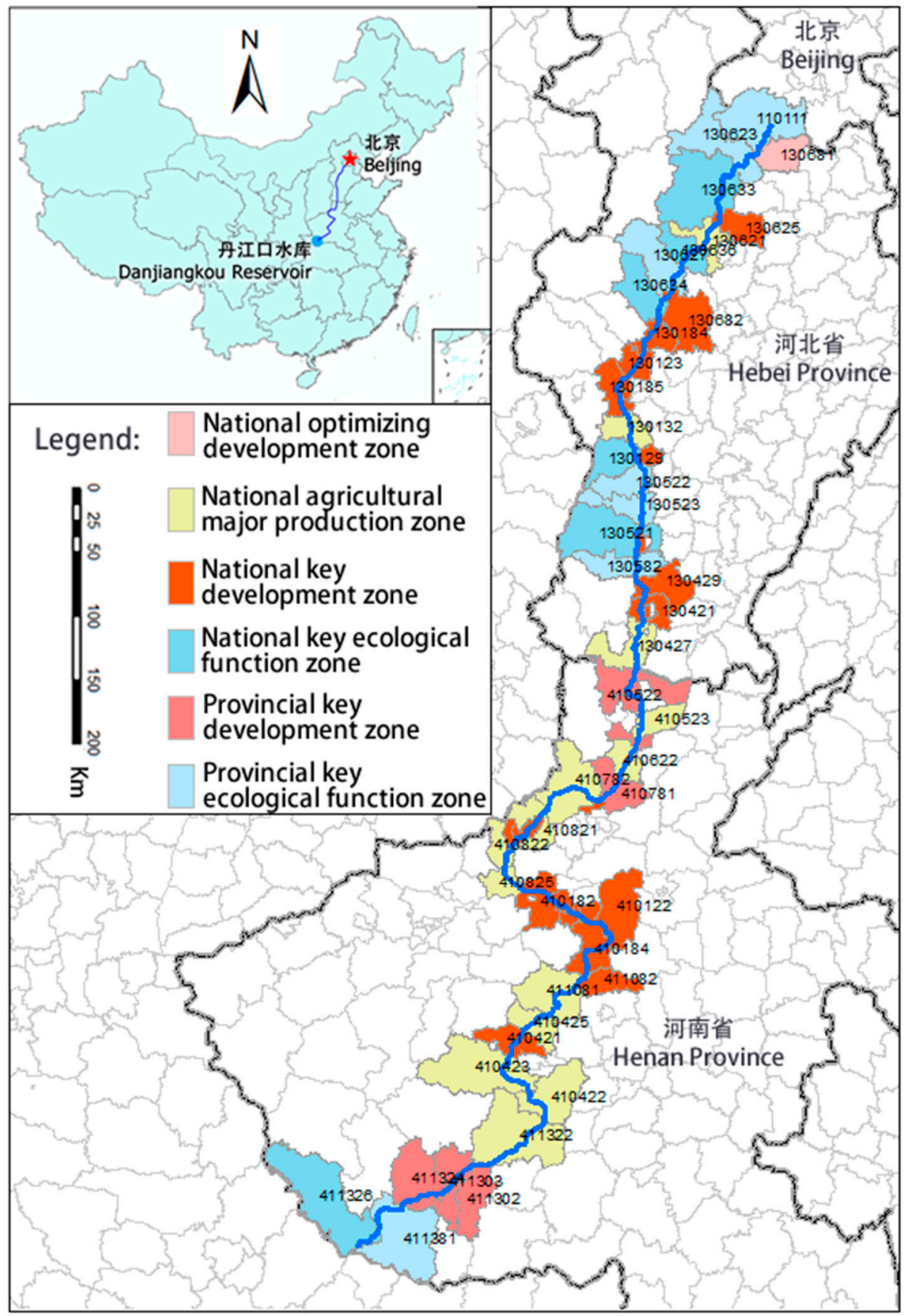

Figure 1. Counties (postcode) in Henan and Hebei along the trunk canal of the middle route of the South-to-North Water Diversion Project.

The middle route of the South-to-North Water Diversion Project runs through the catchment areas of 219 rivers. Each of them has a catchment area of more than $10 \mathrm{~km}^{2}$ [4]. It connects the four major river basins of China: The Yangtze River, the Huaihe River, the Yellow River, and the Haihe River. In addition, there are various types of trunk canals being constructed, including excavated open channels, mound open channels, closed channels, leap-type aqueducts, and underpass inverted siphons [5]. Because of the variety of landscapes along the route (e.g., towns, counties, riparian lands, and hills), protecting the quality of water has become a complicated and challenging issue [6]. The key to ensuring water quality is to scientifically evaluate the pressures on water quality in the area along the route and to identify sensitive areas subjected to various types of pressures. 
The research on the water quality in the middle part of the South-to-North Water Transfer Project have mainly focused on four aspects:

(1) Evaluation of water yield and water quality. For instance, Yan and Chen (2013) evaluated the amount of transferred water in drought years and found that there was a risk of water shortage [7]. Lin et al. (2016) assessed both the water quality and water yield of the middle route [8]. The results showed that: (1) High algae in high temperature periods and low turbidity in low temperature had adverse effects on water plant functioning; and (2) the total water yield of the middle route was high, while there was an uneven distribution in dry years.

(2) Analysis of sources and causes of key pollutants: Liang et al. (2017) analyzed water quality changes from monitoring the data from 26 stations and showed that the main pollutants, such as COD (chemical oxygen demand), Mn, ammonia nitrogen, total nitrogen, and total phosphorus had increasing trends. For instance, both the COD and total nitrogen of the entire canal had grown, with ranges of $1.75-2.58 \mathrm{mg} / \mathrm{L}$ and $0.76-1.40 \mathrm{mg} / \mathrm{L}$ from 2004 to 2014, respectively [9]. In addition, the trunk canal water quality is probably influenced by several kinds of sources, e.g., direct water pollution, atmospheric dust precipitation, rain pollution from bridge floors, sediment pollution, leaching pollution by municipal solid waste (MSW) landfills, storm water pollution, and polluted underground water, as well as the relevant prevention and control countermeasures. Lin (2017) summarized several features of the central line project design and its current operation. In addition, he analyzed the changes in total nitrogen, ammonia nitrogen, total phosphorus, and the permanganate index along the middle route. The main risks were the growth and reproduction of algae and frogs [10].

(3) Changes in land use and the ecological environment: Dong et al. (2016) conducted research on the construction area of a large water conveyance pipeline project in Yi County, Hebei Province, in the middle route of the South-to-North Water Diversion Project, based on three-stage remote sensing image data (i.e., before construction, during construction, and after construction). It was found that disturbance caused by human activities increased gradually with the construction of the water conveyance pipeline route, which had evident impacts on the vegetation and soil ecosystem [11]. Yin et al. (2017) conducted research in Xichuan County, the core water source area in the middle route of the South-to-North Water Diversion Project, using remote sensing data. The land use change from 2004 to 2014 was quantified, and the results showed that while the quality of the ecological environment in Xichuan County had improved in general, the ecological environment in local regions had decreased during the research period. For example, the most prominent negative impacts on the ecological environment originated from excessive exploitation, reclamation, and extensive management of the forest resources, which were incentivized by economic benefits [12].

(4) Evaluation of project benefits and risk with multi-criteria analysis: Guo et al. (2017) established a comprehensive evaluation index system for the ecological environment in the areas along the middle route of the South-to-North Water Diversion Project by combining an ecological environmental condition index with a "pressure-state-response" model. The results showed that most of the county-level cities were in a 'Medium' or 'Dangerous' environmental quality status in 2014 [13]. Wu (2018) identified key areas for water and soil conservation and confirmed that areas with high priority covered $5.74 \%$ of drainage areas through the evaluation of soil erosion and nutrition concentration in the upstream regions [14]. Yang et al. (2018) analyzed biomass differences in riparian buffers in the water source via Landsat remote sensing data [15].

Most researchers focused on specific pollutants and representative study areas. However, comprehensive pressures on water quality protection along the full canal route should still be explored. In addition, previous studies were mainly based on engineering and technical considerations, while the combination of environmental policies and regulations was ignored. It is widely agreed that the main issues of water quality risk control should include assessments of environmental emergency, the quality of surface water, air quality, and groundwater quality. The former three factors are influenced by disturbances from surrounding human activities, and the last one is affected by the relationship between the excavation depth of the project and the groundwater level. This paper aims to analyze the 
pressures on water quality from human activities, the excavation effect, and comprehensive impact factors using data from Land Use and Land Cover (LULC) change and terrain analysis elevation. This paper also puts forward strategies for decision support in China's environmental policies, e.g., those related to main functional zones and ecological red lines.

\section{Methods}

\subsection{Research Area}

According to the Chinese national main functional zoning, the maximum buffer radius for second-level drinking water resource protection is $2 \mathrm{~km}$. Therefore, this paper studied the $2-\mathrm{km}$ radius buffer areas on both sides of the trunk canal in the Henan and Hebei provinces, which included 69 counties. An open canal in Fangshan District of Beijing was also taken into consideration, although it was not used in the final protection pressure assessment since it was too short to be counted compared with the others in the Henan and Hebei provinces. While the trunk canal flows directly through 61 counties, only 9 counties have the protection buffer areas. According to the Chinese national main functional zoning [16], the research area involves 1 national level optimizing development zone (county), 25 national key development zones (counties), 8 provincial key development zones (counties), 14 national agricultural major production zones (counties), 6 national key ecological function zones (all of them are water conservation zones), and 7 provincial key ecological function zones (counties). They are shown in Figure 1.

\subsection{Types of Water Quality Risks}

In addition to sudden environmental risks, the main risks commonly identified for water quality protection along the trunk canal for the mid-route of the South-to-North Water Diversion Project include surface water pollution, atmospheric sedimentation, and groundwater seepage contamination.

\subsubsection{Risk of Surface Water Pollution}

The design of the trunk canal ensures that there is no discharge outlet in the canal and that the canal is completely isolated from the crossed river, eliminating the possibility of industrial and residential waste water along the route. As the trunk canal directly passes through the mountains and the hilly areas, there are still risks from an outbreak of large-scale flooding, carrying the surrounding surface pollutants into the dry canal and affecting the water quality of the dry canal [17].

\subsubsection{Risk of Atmospheric Deposition Pollution}

Due to some causes, such as waste gas from factory and dust from bare ground, excess emissions of air pollution along the route occur frequently. The emitted air pollutants exceed the atmospheric environmental capacity of this region, resulting in poor air quality. In addition, the open channels increase the exposure area of the water to the polluted atmosphere so that toxic and harmful substances in the atmosphere will enter the trunk canal through precipitation or natural settlement, and then the water quality will be affected.

\subsubsection{Risk of Groundwater Seepage Pollution}

The open channel is an important component of the trunk canal (the length of the open channel is about $1100 \mathrm{~km}$ ). It depends on gravitational flow. A large number of deep excavation sections exist along the front of the mountain (see in Section 3.2), which means there is a higher groundwater level outside the channel compared with the water level inside the channel. In order to meet the requirements of type III water quality along the trunk canal, unidirectional anti-seepage technology is used; this technology can interrupt the water flow from channels to the groundwater zone, but directional reversal is permitted. Despite this, canal portions with deep excavation suffer the risk of water pollution by groundwater seepage. Compared with the other two risks mentioned above, the negative impact 
on water quality from groundwater seepage is slower and harder to detect, and this lasting negative impact cannot be eliminated within a short time.

The main factors impacting water risk mentioned above are the types of businesses and industries along the trunk canal and the excavation project. A higher intensity of human activity (both industry and residential) usually causes a higher water pollution (groundwater included). In addition, a deeper excavation usually causes a higher seepage risk from polluted groundwater. In this way, the main issue in assessing the pressures on water quality protection is how to accurately assess human activity disturbance and the depth of excavation.

\subsection{Data Source}

\subsubsection{Medium Resolution Land-Use Classification Data}

The images (30 $\mathrm{m}$ resolution) utilized for Land Use Land Cover (LULC) Classification were from the National Ecosystem Research Network of China (http://www.cnern.org.cn/). 18 land cover types were reclassified into 6 categories as farmland, grassland, woodland, wetland, construction land, and unexploited land, corresponding to the local classification system.

\subsubsection{Retrieving Land Surface Temperature (LST)}

Based on the Landsat 8 image ( $30 \mathrm{~m}$ resolution) from July 2015, the surface temperatures of Cixian and Anyang County in the middle section of the South-to-North Water Diversion Project were obtained using Ren Huazhong's surface temperature interpretation method [18]. The average land surface temperature was calculated from both day and night data. The change of surface temperature was used to describe the disturbance intensity of human activities (land-use change). The data were obtained from the United States Geological Survey (http:/earthexplorer.usgs.gov).

\subsubsection{Elevation Data}

The canal's elevation data (bottom of canal) were obtained from the Office of South-to-North Water Diversion Project. The resolution for the canal's elevation data was $50 \mathrm{~m}$ after an interpolation. The elevation data for the original land surface were obtained from NASA, which had a resolution of $30 \mathrm{~m}$.

\subsection{Methodological Framework}

Figure 2 showed the technical route of this paper.

Firstly, the human activity index was calculated for each type of land-use. This index was an original idea which used the average surface temperature of each land-use type to stand for the activity level of each area. Christidis et al. (2011) analyzed the human activity response to extreme daytime temperature [19]. Ning et al. (2018) introduced the relationship between surface temperature and land-use cover [20]. Both of them implied the rule that higher human activity usually leads to higher surface temperatures. Surface temperature data were calculated by the interpretation data of Landsat 8 from July, 2015.

Secondly, the human disturbance status of 2015 was calculated with the land-use data and human activity index. This status indicator represented the current situation of human activity disturbance to natural ecosystems in the research area.

Thirdly, human disturbance trends were calculated with the land-use change data (land-use transfer matrix from 2005 to 2015) and the human activity index. This trend indicator represented the changing trend in the research area under usual situations.

Fourthly, the excavation depth of this canal was also considered as a key indicator of water protection risk. It was identified as the difference value of the original trunk canal elevation compared to the arterial canal bottom elevation. However, all the mounding areas were excluded, as mounding areas are usually easy to protect from pollution. 


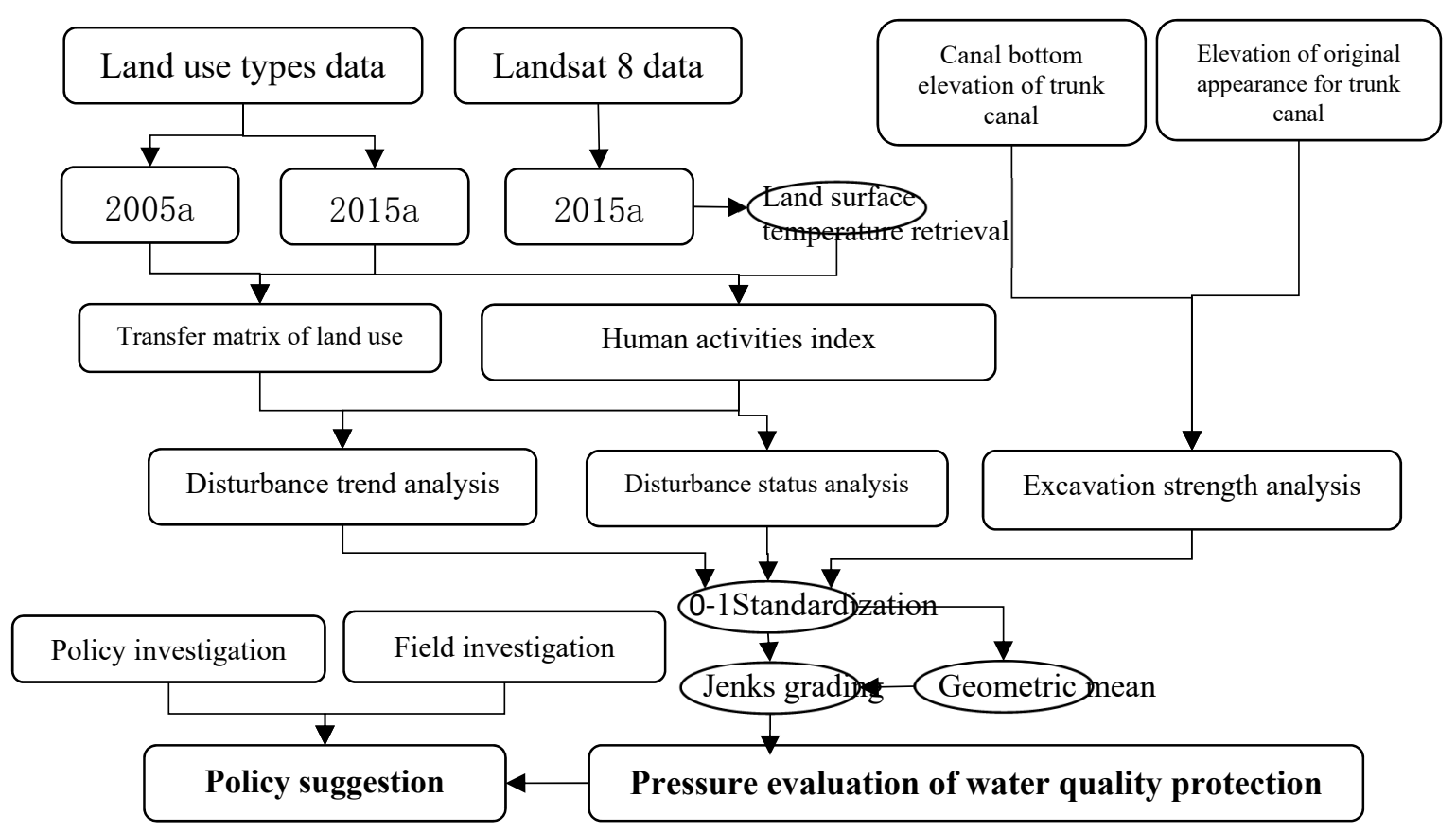

Figure 2. Methodological framework for assessing water quality protection for water diversion projects.

Fifthly, 0-1 standardization was conducted for each of the above 3 indicators separately. The standardization result of each indicator was graded into 5 levels by the Jenks Natural Breaks grading method [21]. In this way, comparison among different counties became easier, and a comprehensive result could be formed after eliminating the effects caused by the different units of the 3 indicators.

Finally, comprehensive water protection stress was calculated by a geometric mean method with the standardization results of the 3 indicators. The comprehensive stress indicator was graded into 5 levels by the Jenks grading method, as well.

\section{Results}

\subsection{Composition and Changes in Land Use}

In 2015 , the total area of the $2-\mathrm{km}$ radius buffer areas along the canal were $488,657 \mathrm{ha} .72 .70 \%$ of this was agriculture land, and $20.90 \%$ was construction land. The amount of woodland, wetland, and grassland decreased in sequence. Compared with 2005, the area of construction land increased the most (the net growth was 24,514 ha), while the area of agriculture land decreased the most (the net reduction was 22,842 ha). Additionally, the area of grassland and woodland decreased, while the area of wetland increased (Figure 3).

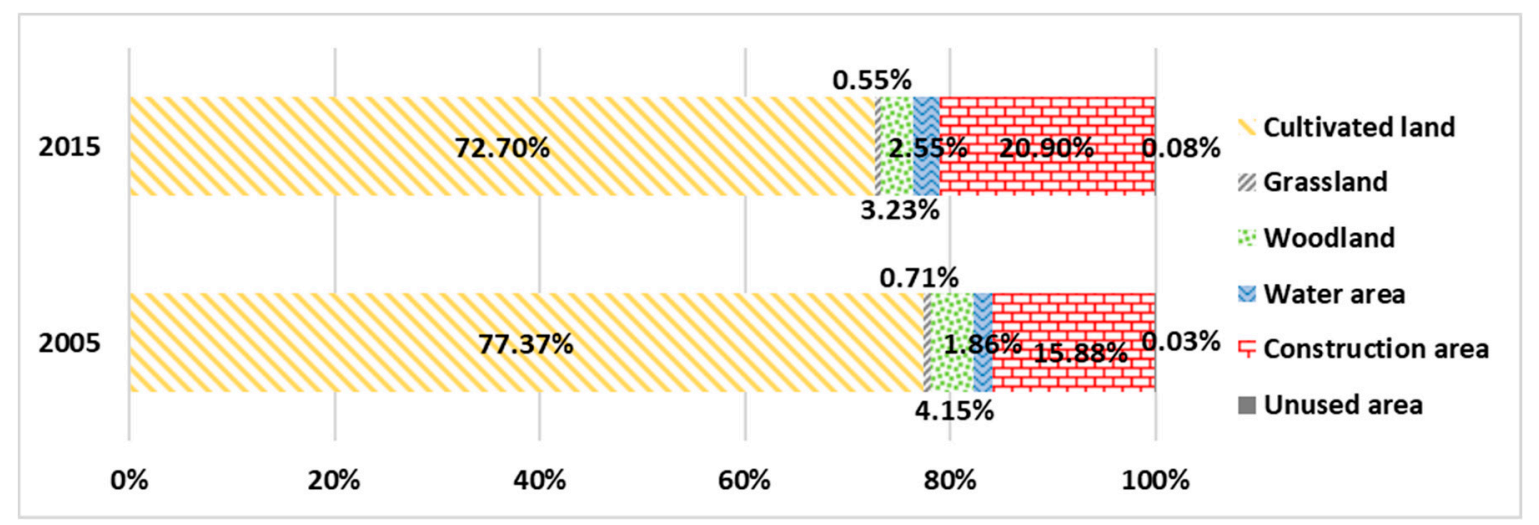

Figure 3. Composition of land use in the 2-km buffer area along the trunk canal. 
According to the land-use transfer matrix (Table 1), there were more than 30 different types of land-use changes. The most drastic five types were "agriculture land to construction land" (25,590 ha), "construction land to agriculture land" (3921 ha), "agriculture land to wetland" (3670 ha), "woodland to construction land" (2472 ha), and "woodland to agriculture land" (1992 ha).

Table 1. Land-use transfer matrix.

\begin{tabular}{cccccccc}
\hline & & & To 2015a & & \\
\hline & Unit: Hectare & Agriculture land & Grassland & Woodland & Water area & Construction land & Unused land \\
& Agriculture land & $347,870.52$ & 117.00 & 783.27 & 3670.38 & $25,589.88$ & 44.10 \\
From & Grassland & 605.70 & 2376.27 & 82.62 & 62.91 & 350.73 & 0.00 \\
$2005 \mathrm{a}$ & Woodland & 1991.97 & 152.28 & $14,539.68$ & 1050.93 & 2472.48 & 77.94 \\
& Water area & 814.59 & 2.25 & 179.37 & 7576.20 & 299.07 & $73,381.50$ \\
& Construction land & 3921.39 & 25.11 & 130.68 & 116.91 & 17.69 & 63.64 \\
& Unused land & 29.34 & 0.00 & 45.81 & 0.18 & 63.63 \\
\hline
\end{tabular}

\subsection{Current Situation and the Trend in Human Activity Disturbance}

The relationship between surface temperature and land-use type was calculated with the data from the central research area, which was Ci County (Hebei Province) and the neighboring Anyang County (Henan Province) area. It was shown that construction areas had the highest surface temperature (Figure 4), and water had the lowest. This result, which conforms to earlier studies [19,20], reveals that construction areas usually have the highest human activity disturbance and the highest temperature. Based on the data from Figure 4, the situation of each county can be calculated with the composition of its land-use, as seen in Figure 5. The difference between 2005 and 2015 showed the tendency of human activity change (Figure 6). Data in Figures 5 and 6 were processed with a $0-1$ standardization for further analysis.

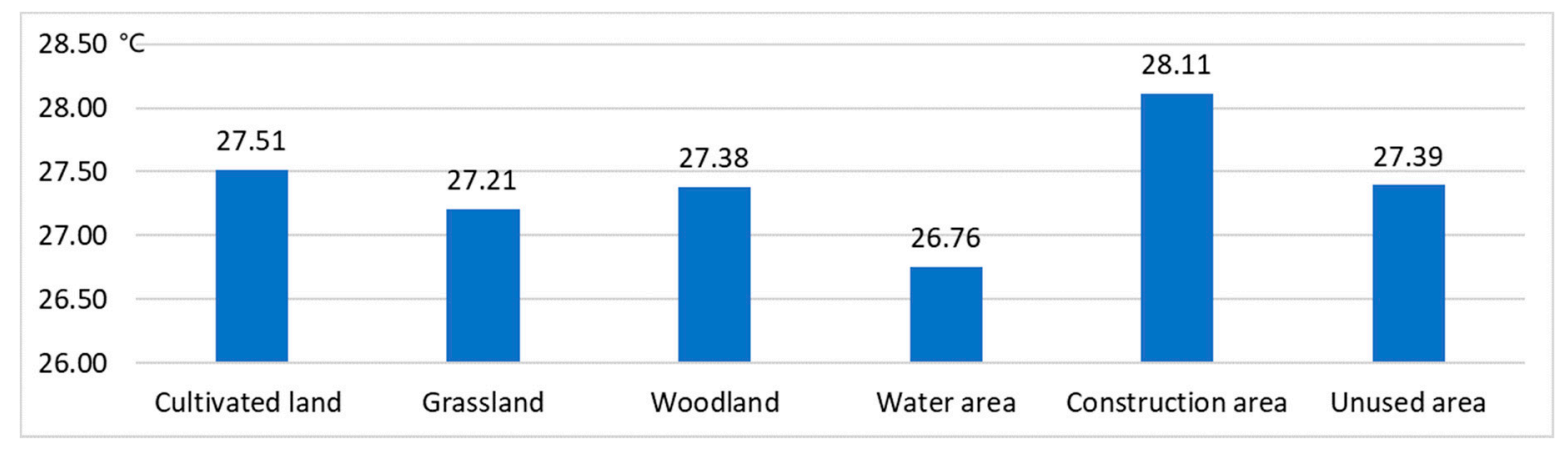

Figure 4. Human activity strength in different land-use types (average surface temperature, ${ }^{\circ} \mathrm{C}$ ).

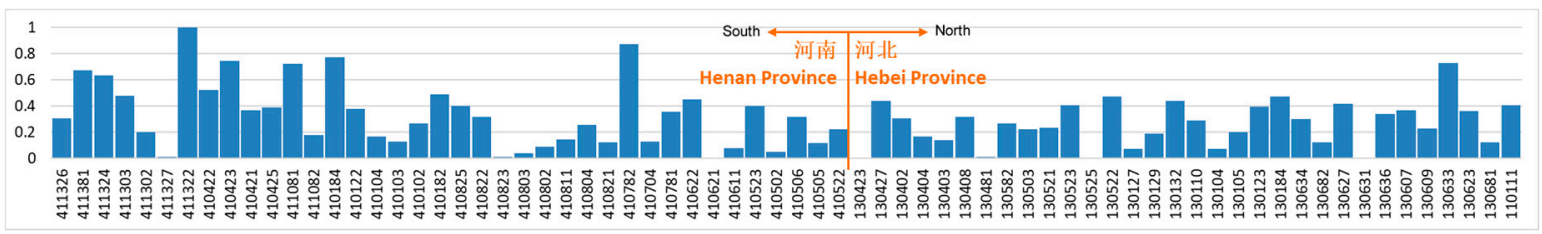

Figure 5. Human activity in the region along the trunk canal in 2015.

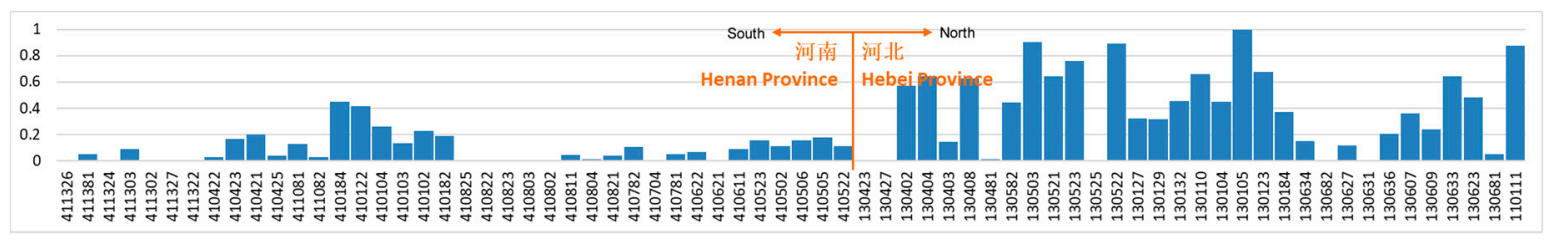

Figure 6. The trend in human activity in the region along the trunk canal from 2005 to 2015. 
According to Figure 5, Henan Province had a worse disturbance situation than Hebei Province in 2015. However, Hebei Province had a worse tendency, according to Figure 6.

\section{Depth of Canal Excavation and Mound}

The excavation/mound depth was obtained by calculating the difference between the elevation of the canal's bottom and the elevation of the original land surface. A negative value in Figure 7 means an excavation area, while a positive value means a mound area. The average excavation depth of Henan and Hebei was similar. However, Henan had more excavation areas, which meant a higher groundwater seepage risk.

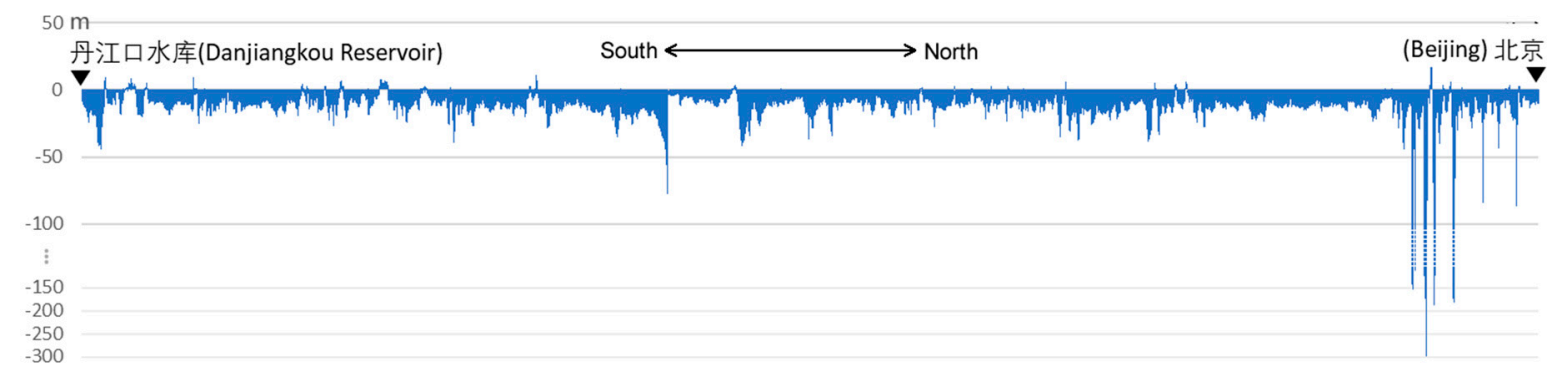

Figure 7. Excavation and filling depth of the trunk canal in the mid-route section of the South-to-North Water Diversion Project (m).

\subsection{Water Quality Protection Pressure}

Table 2 shows the water protection stress in the Hebei and Henan provinces in five levels. Rank I (with the darkest color) means the most serious situation. The postal code listed in each cell stands for

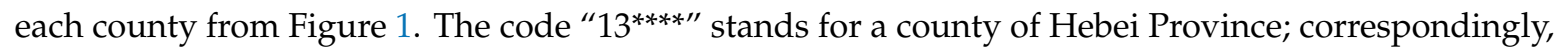
" $41^{* * * * "}$ stands for a county of Henan Province. The method for the grading was introduced in Section 2.4. According to Table 2, Hebei's average rank value was 3.68, which was higher than Henan's (4.42). This meant Hebei had a more serious comprehensive situation. 
Table 2. Pressure classification of water quality protection along the middle route of the South-to-North Water Diversion Project (postal code for counties in the Henan and Hebei provinces).

\begin{tabular}{|c|c|c|c|c|c|c|c|c|c|c|c|}
\hline \multicolumn{3}{|c|}{$\begin{array}{c}\text { Disturbance Status } \\
\text { Grading }\end{array}$} & \multicolumn{3}{|c|}{$\begin{array}{c}\text { Disturbance Trend } \\
\text { Grading }\end{array}$} & \multicolumn{3}{|c|}{$\begin{array}{l}\text { Excavation Depth } \\
\text { Grading }\end{array}$} & \multicolumn{3}{|c|}{$\begin{array}{c}\text { Comprehensive Stress } \\
\text { Grading }\end{array}$} \\
\hline 130681 & 130623 & 130633 & 130681 & 130623 & 130633 & 130681 & 130623 & 130633 & 130681 & 130623 & 130633 \\
\hline 130609 & 130607 & 130636 & 130609 & 130607 & 130636 & 130609 & 130607 & 130636 & 130609 & 130607 & 130636 \\
\hline 130631 & 130627 & 130682 & 130631 & 130627 & 130682 & 130631 & 130627 & 130682 & 130631 & 130627 & 130682 \\
\hline 130634 & 130184 & 130123 & 130634 & 130184 & 130123 & 130634 & 130184 & 130123 & 130634 & 130184 & 130123 \\
\hline 130105 & 130104 & 130110 & 130105 & 130104 & 130110 & 130105 & 130104 & 130110 & 130105 & 130104 & 130110 \\
\hline 130132 & 130129 & 130127 & 130132 & 130129 & 130127 & 130132 & 130129 & 130127 & 130132 & 130129 & 130127 \\
\hline 130522 & 130525 & 130523 & 130522 & 130525 & 130523 & 130522 & 130525 & 130523 & 130522 & 525 & 130523 \\
\hline 130521 & 130503 & 130582 & 130521 & 130503 & 130582 & 130521 & 130503 & 130582 & 130521 & 130503 & 130582 \\
\hline 130481 & 130408 & 130403 & 130481 & 130408 & 130403 & 130481 & 130408 & 130403 & 130481 & 130408 & 130403 \\
\hline 130404 & 130402 & 130427 & 130404 & 130402 & 130427 & 130404 & 130 & 130427 & 13 & 402 & 130427 \\
\hline 130423 & 410522 & 410505 & 130423 & 410522 & 410505 & 130423 & 41 & 410505 & 13 & 522 & 410505 \\
\hline 410506 & 410502 & 410523 & 410506 & 410502 & 410523 & 410506 & 410502 & 410523 & 410506 & 410502 & 410523 \\
\hline 410611 & 410621 & 410622 & 410611 & 410621 & 410622 & 410611 & 410621 & 410622 & 410611 & 410621 & 410622 \\
\hline 410781 & 410704 & 410782 & 410781 & 410704 & 410782 & 410781 & 410704 & 410782 & 410781 & 410704 & 410782 \\
\hline 410821 & 410804 & 410811 & 410821 & 410804 & 410811 & 410821 & 410804 & 410811 & 410821 & 410804 & 410811 \\
\hline 410802 & 410803 & 410823 & 410802 & 410803 & 410823 & 410802 & 410803 & 410823 & 410802 & 410803 & 410823 \\
\hline 410822 & 410825 & 410182 & 410822 & 410825 & 410182 & 410822 & 410825 & 410182 & 410822 & 410825 & 410182 \\
\hline 410102 & 410103 & 410104 & 410102 & 410103 & 410104 & 410102 & 410103 & 410104 & 410102 & 410103 & 410104 \\
\hline 410122 & 410184 & 411082 & 410122 & 410184 & 411082 & 410122 & 410184 & 411082 & 410122 & 410184 & 411082 \\
\hline 411081 & 410425 & 410421 & 411081 & 410425 & 410421 & 411081 & 410425 & 410421 & 411081 & 410425 & 410421 \\
\hline 410423 & 410422 & 411322 & 410423 & 410422 & 411322 & 410423 & 410422 & 411322 & 410423 & 410422 & 411322 \\
\hline 411327 & 411302 & 411303 & 411327 & 411302 & 411303 & 411327 & 411302 & 411303 & 411327 & 411302 & 411303 \\
\hline 411324 & 411381 & 411326 & 411324 & 411381 & 411326 & 411324 & 411381 & 411326 & 411324 & 411381 & 411326 \\
\hline \multicolumn{7}{|c|}{$\begin{array}{l}\text { Tips: the figures are zip codes of each county, the top left corner } \\
\text { is the northernmost, the lower right is the southernmost, and } \\
\text { they are arranged in a "Z" shape. The I-level pressure is the } \\
\text { highest, and V the smallest. }\end{array}$} & I & II & III & IV & V \\
\hline
\end{tabular}

\section{Discussion}

\subsection{Causes of Land-Use Change along the Canal}

During the research period, approximately 25,590 ha of agricultural land were transformed into construction lands. On the one hand, approximately 12,000 ha of impervious surface were newly built for the middle route of the South-to-North Water Diversion Project as necessary infrastructure (considering a 50-m radius buffer on each side of the trunk canal). Thus, trunk canal engineering was one of the main reasons for the reduction of agricultural lands. On the other hand, assuming that those reduced construction lands (4212 ha) during the study period were caused by residential resettlement for canal construction, the same area of residence should have been rebuilt in the study area. It can be calculated that almost 9300 ha of agricultural lands were transformed into construction lands by urbanization rather than from canal engineering.

The area of new wetlands (4901 ha) was similar to the total area of water in the canal. This hinted that canal engineering was the main reason for the wetland increase. However, during the same period, 1114 ha of wetland were transformed into construction land and agricultural land. This showed that human activity was the main reason for land-use change as well.

\subsection{Features of Human Activity Disturbance}

The land surface temperature characteristics can reflect the disturbance from human activities along the trunk canal. Based on the disturbance intensity coefficients of all land-use types (Figure 4), the order of human activity disturbance from strong to weak was: Urban space, agricultural land, and water, which is consistent with common sense. However, the disturbance intensity of the woodland 
was higher than that of grassland. The reason was that the areas surrounding the trunk canal were rural areas, on which there were lots of agricultural production activities. Most woodland areas here were economic woodland with production activities, rather than natural forests. In addition, the area of grassland in the study area was very small, and most of it consisted of river banks or abandoned land with few human activities. Therefore, the human disturbance of woodland was higher than that of grassland. In this way, these uncommon findings fit the local situation.

Moreover, as shown in Figure 4, the increase of construction lands caused an increase in human disturbance. In 2015, the study area in Henan Province had a higher human disturbance level because it had a larger construction land area compared to Hebei. However, the study area in Hebei Province had a worse human disturbance tendency due to its higher urbanization rate.

\subsection{Performance of Construction Land Expansion Controls}

Currently, there are two types of statutory protected areas along the trunk canal. One is the project management and protection area, which is within 20 to $100 \mathrm{~m}$ (depending on the construction conditions of the project) on both sides of the canal. The second type is the drinking water resource protection area, which includes the first and second levels of drinking water resource protection areas. The first level is 100-200 m out of range of the project management (depending on the water and groundwater level of the trunk canal and the drainage pathway for groundwater), and the second level is $950-2000 \mathrm{~m}$ out of the range of the first level. In order to facilitate research, this study divided those protection areas into three types: the project protection area (L0, within a 100-m radius), the first level water source protection area (L1, in a 100- to 300-m radius), and the second level water source protection area (L2, in a 300- to 2000-m radius). The area of project protection is limited and is protected by a metal fence. Therefore, we decided not to conduct research on the land change in L0 and only conducted statistical analysis on the increase in new construction land in L1 and L2.

Figure 8 was generated from statistical analysis of construction lands within the estimated ranges of primary water source protection areas (L1) and secondary water source protection areas (L2). In Hebei Province, from 2005 to 2015, the net increase of urban construction land in L1 was 1302 ha (with an average annual growth rate of $6.82 \%$ ), and the net increase of construction land in L2 was 17,539 ha (with an average annual growth rate of 5.67\%). In Henan Province, from 2005 to 2015, the net increase of construction land in L1 was 213 ha (with an average annual growth rate of $0.55 \%$ ), and the net increase of construction land in L2 was 3907 ha (with an average annual growth rate of $0.83 \%$ ). It can be seen that Henan Province had greater success in the control of disturbance than Hebei Province.
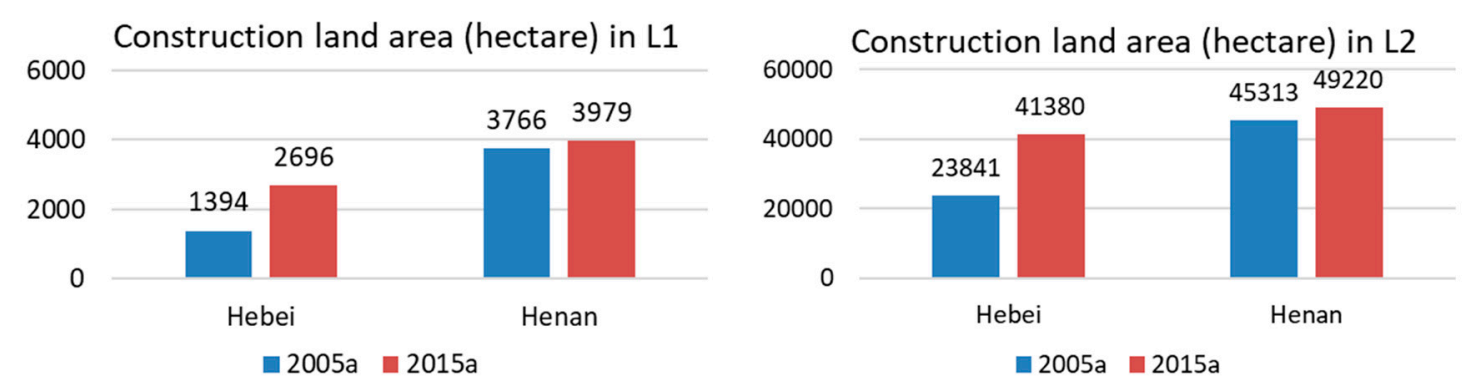

Figure 8. Construction land area in L1 and L2 protection areas (approximately).

\subsection{Scale Differences among Different Pressure Levels}

This article used the Jenks grading method [21] to classify counties into five different pressure levels to make the policy suggestions more pertinent to each level. However, it was hard to identify the differences between two pressure levels accurately. In order to solve this problem, this article calculated the average score for each level, and then used the average score to stand for that level. Finally, the quantitative differences among different pressure levels are displayed in Figure 9. This is helpful in 
setting a different management scheme for each different level. For instance, the frequency of inspection in level I areas should be 2.3-times higher than in level II areas, according to the comprehensive pressure differences shown in Figure 9.

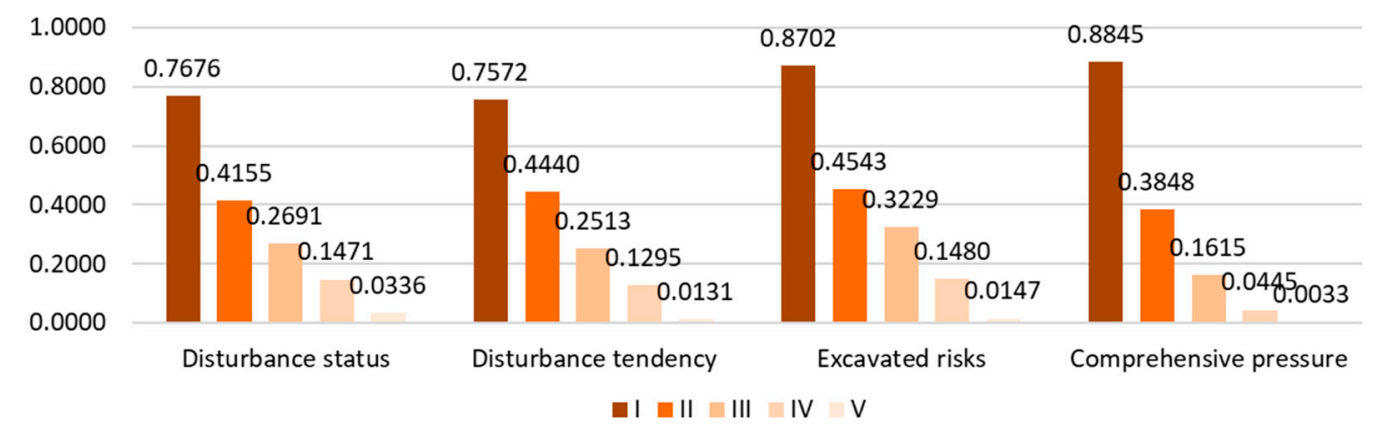

Figure 9. Quantitative differences among different pressure levels

\section{Policy Suggestions}

\subsection{Policy Suggestions for Different Types of Pressure}

Based on the pressure types shown in Table 2 and the quantitative relationships of the five levels of pressure shown in Figure 9, this research provides the following suggestions: (1) For areas with high pressure of disturbance status, illegal buildings in protection zones should be eliminated, and the monitoring of surface water pollution, non-point source pollution, and air pollution should be carried out; (2) for areas with a high disturbance pressure trend, local government officials should be held accountable for the growth of urban construction land in recent years; (3) monitoring of the groundwater level and water quality should be carried out in areas with high risks of groundwater infiltration; (4) comprehensive supervision and environmental monitoring should be adopted in areas with high comprehensive risk pressure; and (5) management resources should be allocated, and the management intervention intensity should be differentiated among counties according to the quantitative relationships among the pressure levels.

\subsection{Policy Suggestions for Different Types of Landscapes}

Based on the remote sensing interpretation and field monitoring, the landscape characteristics of the study area can be summarized as construction landscape areas (urban buildings, including intensive residential areas or factory towns on both sides, such as the Jiaozuo Section), riparian landscape areas (river channel and river rapids on both sides, such as the Yellow River Section), rural landscape areas (farmland and rural residential areas on both sides; most of the research areas are this type), and hilly landscape areas (area across or between two mountains, such as Mancheng County). The following suggestions are recommended for different landscapes to promote China's national main functional zoning policy at the provincial and prefecture-city level.

For the urban construction landscape areas, considering the features of urbanization, such as industrialization, impermeable surface growth, and urban inundation, the following are suggested: (1) Illegal buildings in protected areas should be abandoned; (2) urban development should focus on the east bank (with a lower elevation) of the canal; (3) storm water, flood networks, and domestic sewage pipe networks should be improved and well-maintained on the western bank (with a higher elevation); (4) the monitoring of groundwater hydrology and water quality should be strengthened; and (5) the monitoring of air pollution should be strengthened.

For the riparian landscape areas, considering their farming and wetland features, this article suggests: (1) Remove illegal farmland and farmhouses, and (2) strengthen the management of the river channel to restore the catchment and flood discharge capacities of the river channel. 
For the rural landscape areas, considering the non-point resource pollution problem close to forests [22], the following are recommended: (1) Remove illegal agricultural lands and construct ecological forest belts; (2) control the use of chemical fertilizers and encourage the development of ecological agriculture; (3) strengthen the construction of water conservancy facilities in farmland areas; (4) investigate and repair the sewage and irrigation facilities truncated by the trunk canal; and (5) strengthen the monitoring of the surrounding surface water and groundwater quality.

For the hilly landscape area, where landslides are the main risk, they should force on the following: (1) Improve the management of stony desertification and bare rocks, and (2) promote mountain slopes management to prevent landslides and to strengthen protection.

\subsection{Policy Suggestions Based on the Ecological Protection Red Lines Policies}

China has implemented ecological red lines policies, which set strict protection boundaries and thresholds to ensure the ecosystem services, environment quality, and sustainable natural resource utilization [23]. At present, the canal management reserve area and drinking water protection area have no clear or stable financial compensations, which will greatly hamper the protection of riparian environments and water quality in the canal.

Therefore, it is suggested that the primary drinking water source protection area along the trunk canal should be included in ecological protection red lines to obtain ecological compensations for forest belt planting and to solve the fund shortage problem. Additionally, in this way, protection could be strengthened by double restraints from both water conservation policies and ecological protection red lines policies. In addition, if it is necessary, even the secondary drinking water protection area should be included into ecological protection red lines for greater support.

\subsection{Policy Suggestions Based on the Main Functional Zones Policy}

The main functional zones strategy is a long-term development strategy for China's land. It was identified as the basis of the overall plan for the national economy and social development, population planning, regional planning, city planning, and environment protection planning. According to the main functional zones strategy, Chinese land is classified into four different types at the county level, including the optimizing development zone, key development zone, major agriculture zone, and important ecological zone. Both the optimizing development zone (county) and the key development zone (county) have urbanization as their functional orientation [23]. The water quality protection for the trunk canal of the middle route of the South-to-North Water Transfer Project should be organized on the basis of the different main functions of each county (Figure 1).

Firstly, it is essential that both the key development zones and optimizing development zones take economic development as their primary goal. Suggestions are proposed for water quality protection in those counties as follows: (1) Urban expansion should occur on the west side of the trunk canal; (2) the drainage facilities across the canal should be updated in timely fashion according to urban development scale; and (3) the environmental impact assessment of the activity management within the red lines of the water source area and of the economic activities outside the red lines should be strengthened.

Secondly, for the major agriculture zones, which are prioritized to enhance agricultural production, the following points should be considered: (1) Encourage the development of ecological agriculture which cause less water pollution, such as organic planting and circular agriculture; (2) promote the application of advanced organic farming techniques with less pollution and fertilization; (3) strengthen the monitoring of groundwater quality in adjacent canal areas; and (4) promote the construction of irrigation infrastructures, especially those crossing the trunk canal.

Thirdly, priority should be placed on improving the capacity of ecosystem services in those important ecological zones, especially the water purification service from wetlands and the non-point resource pollution retention service from forests and grasslands. Regarding water quality protection in these counties, this study suggests: (1) Strictly abiding by ecological protection red lines and their 
management restrictions; (2) enhance the planting of the ecological forest belt; and (3) regularly carry out ecosystem services capacity assessments.

\section{Conclusions}

The main conclusions of this article are the following:

(1) Intense land-use change took place within the 2-km buffer zone along the trunk canal from 2005 and 2015. There was a significant increase of construction land and a considerable decrease in agriculture land. This was due to rapid urbanization. In addition, the growth rate of construction land in Hebei was significantly higher than in Henan Province.

(2) In 2015, the disturbance pressure of human activities in Henan Province was higher than that in Hebei, while the disturbance trend pressure was the opposite. Two types of pressures were mainly positively influenced by urban land increase. The groundwater seepage pressure of excavated areas in Hebei was slightly higher than in Henan, and the comprehensive pressure in Hebei was higher than in Henan.

(3) This article provides detailed policy and regulation suggestions to mitigate pressures on water quality. Those suggestions should be applied according to the different water quality protection pressures and different landscape compositions at the local scale. In addition, a wide range of Chinese ecological and environmental policies were considered as policy tools for water quality protection along the canal. Take the drinking water resource protection policy, ecosystem protection red line policy, and main functional zoning policy as examples-they provide important guidelines for the development of the water diversion area in order to secure water quality.

Author Contributions: Conceptualization, Z.O. and B.H.; methodology, B.H.; software, N.M.; validation, Z.O., B.H. and N.M.; formal analysis, B.H.; investigation, N.M., J.Z., B.H. and L.K.; resources, Z.O.; data curation, J.Z. and L.K.; writing-original draft preparation, B.H.; writing—review and editing, W.C., T.W., B.H.; visualization, N.M. and B.H.; supervision, Z.O.; project administration, Z.O.; funding acquisition, Z.O.

Funding: This research was supported by the Natural Science Foundation of China (Grand No. 71533005 and No. 71804180.

Conflicts of Interest: The authors declare no conflict of interest.

\section{References}

1. Zhuang, W. Eco-environmental impact of inter-basin water transfer projects: A review. Environ. Sci. Pollut. Res. 2016, 23, 12867-12879. [CrossRef]

2. Zhao, Z.; Zuo, J.; Zillante, G. Transformation of water resource management: A case study of the South-to-North Water Diversion project. J. Clean. Prod. 2017, 163, 136-145. [CrossRef]

3. Liu, K.; Gan, Y.H.; Zhang, T.; Luo, Z.; Wang, J.J.; Gao, X.M.; Yue, Q.X. Study on Land Use Change in the Water Supplying Core Area of Middle Route of South-To-North Water Transfer Project. In Proceedings of the IGARSS 2018-2018 IEEE International Geoscience and Remote Sensing Symposium, Valencia, Spain, 22-27 July 2018; pp. 802-805. [CrossRef]

4. Office of the South-to-North Water Diversion Project Construction Committee, State Council, People's Republic of China the South-to-North Water Diversion Project. Engineering 2016, 2, 265-267. [CrossRef]

5. Wang, L.; Ma, C. A study on the environmental geology of the Middle Route Project of the South-North water transfer. Eng. Geol. 1999, 51, 153-165. [CrossRef]

6. Peng, Z.; Zhang, L.; Yin, J.; Wang, H. Study of impact factors of willingness to pay regarding water reserve of South-to-North Water Diversion Project in Beijing based on Bayesian network model. J. Clean. Prod. 2018, 184, 569-578. [CrossRef]

7. Yan, B.; Chen, L. Coincidence probability of precipitation for the middle route of South-to-North water transfer project in China. J. Hydrol. 2013, 499, 19-26. [CrossRef]

8. $\quad$ Lin, M.; Zhang, Q.; Li, Z.; Zhang, G.; Zhang, Z.; Yang, Z.; Si, S.; Niu, H.; Sun, J.; Fan, H.; et al. Characteristics of the variance of the water quality and quantity in the middle route of South-to-North Water Diversion Project and corresponding measures for urban water supply. J. Water Supply Drain. 2016, 52, 9-13. (In Chinese) [CrossRef] 
9. Liang, J.; Xin, X.; Lu, L.; Hu, S.; Zhu, D.; Tang, J. Analysis of water quality variation and potential pollution sources in main channel of Middle Route Project of South to North Water Diversion. Yangtze River 2017, 48, 6-9. (In Chinese) [CrossRef]

10. Lin, M. Water resource risk and its solutions for the middle route of South-to-North Water Diversion Project. J. Water Supply Drain. 2017, 53, 9-14. (In Chinese) [CrossRef]

11. Dong, M.; Tang, M.; Li, S.; Cao, H.; Deng, H.; Wu, G. Effects of water transfer project construction on vegetation patterns. Acta Ecol. Sin. 2016, 36, 6656-6663. (In Chinese)

12. Yin, G.; Shao, J.; Guo, Y.; Dang, Y.; Xu, X. Study of Land Use Change and Eco-environmental Response in the Core Area ofMid-route of South-to-north Water Transfer Project. J. Geo-Inf. Sci. 2017, 19, 59-69. (In Chinese) [CrossRef]

13. Guo, H.; LIu, R.; Hao, X.; Tian, Z. Eco-environmental evaluation of Middle Route of South-to-North Transfer Project based on PSR model. South-to-North Water Transf. Water Sci. Technol. 2017, 15, 65-70. (In Chinese) [CrossRef]

14. Wu, H. Watershed prioritization in the upper Han River basin for soil and water conservation in the South-to-North Water Transfer Project (middle route) of China. Environ. Sci. Pollut. Res. 2018, 25, 2231-2238. [CrossRef]

15. Yang, S.; Bai, J.; Zhao, C.; Lou, H.; Zhang, C.; Guan, Y.; Zhang, Y.; Wang, Z.; Yu, X. The assessment of the changes of biomass and riparian buffer width in the terminal reservoir under the impact of the South-to-North Water Diversion Project in China. Ecol. Indic. 2018, 85, 932-943. [CrossRef]

16. The Central People's Government of the People's Republic of China. The Notice on the Plan for National Development Priority Zones. Available online: http://www.gov.cn/zwgk/2011-06/08/content_1879180.htm (accessed on 21 December 2010). (In Chinese)

17. Arrighi, C.; Masi, M.; Iannelli, R. Flood risk assessment of environmental pollution hotspots. Environ. Model. Softw. 2018, 100, 1-10. [CrossRef]

18. Li, Z.; Tang, B.; Wu, H.; Ren, H.; Yan, G.; Wan, Z.; Trigo, I.F.; Sobrino, J.A. Satellite-derived land surface temperature: Current status and perspectives. Remote Sens. Environ. 2013, 131, 14-37. [CrossRef]

19. Christidis, N.; Stott, P.A.; Brown, S.J. The role of human activity in the recent warming of extremely warm daytime temperatures. J. Clim. 2011, 24, 1922-1930. [CrossRef]

20. Ning, J.; Gao, Z.; Meng, R.; Xu, F.; Gao, M. Analysis of relationships between land surface temperature and land use changes in the Yellow River Delta. Front. Earth Sci. 2018, 12, 444-456. [CrossRef]

21. Chen, J.; Yang, S.; Li, H.; Zhang, B.; Lv, J. Research on geographical environment unit division based on the method of natural breaks (Jenks). Int. Arch. Photogramm. Remote Sens. Spat. Inf. Sci. 2013, 47-50. [CrossRef]

22. Zhang, L.; Wang, Z.; Chai, J.; Fu, Y.; Wei, C.; Wang, Y. Temporal and Spatial Changes of Non-Point Source $\mathrm{N}$ and $\mathrm{P}$ and Its Decoupling from Agricultural Development in Water Source Area of Middle Route of the South-to-North Water Diversion Project. Sustainability 2019, 11, 895. [CrossRef]

23. Wang, W.; Zhang, X.; Wu, Y.; Zhou, L.; Skitmore, M. Development priority zoning in China and its impact on urban growth management strategy. Cities 2017, 62,1-9. [CrossRef]

(C) 2019 by the authors. Licensee MDPI, Basel, Switzerland. This article is an open access article distributed under the terms and conditions of the Creative Commons Attribution (CC BY) license (http://creativecommons.org/licenses/by/4.0/). 